\title{
Risk-adjusted pricing of project loans
}

\author{
Author Accepted Manuscript (AAM) \\ György Walter, Ph.D., habil \\ Department of Finance, Corvinus University of Budapest \\ 1093 Fővám tér 8, Budapest, Hungary \\ gyorgy.walter@uni-corvinus.hu
}

\begin{abstract}
AAM is under the Creative Commons Attribution Non-commercial International Licence 4.0 (CC BY-NC 4.0). AAM is deposited under this licence and that any reuse is allowed in accordance with the terms outlined by the licence. To reuse the AAM for commercial purposes, permission should be sought by contacting permissions@emeraldinsight.com.
\end{abstract}

\begin{abstract}
Commercial banks were inspired to apply risk-adjusted pricing models for their corporate exposures in the last decade. Project loans represent a sub-segment of corporate loans, where risk parameters are hard to measure, and estimations of default probabilities rely on specific cash-flow simulations. Our research question is whether project finance loans were properly priced based on their risk. We take the usual corporate loan model for calculating risk-adjusted pricing and adapt it to project loans. In our simulation we focus on the European market and estimate the minimum required margins and also the implied maximum probabilities of default, where project loans could produce a value added to lenders besides different margins and leverages. We compare these maximum probabilities of default with reference points of other empirical studies. We conclude that in 2006-2007 several projects were very unlikely to produce any value added for shareholders and pricing did not even reach the minimum margin. We also show that market and regulatory circumstances of 2016-2017 have significantly increased minimum margin levels and must have shifted lenders to a more conservative pricing and leverage policy.
\end{abstract}

JEL Codes: G21, G32, G12, G28

Keywords: Project finance, Pricing, Default prediction; ROC analysis; Bank lending 


\section{Introduction}

Project finance is a segment of corporate loans where contractual structure, stakeholders, the risk valuation methodology, the cash-flow focus, and the non-recourse characteristics differ from that of standard corporate lending. The overall volume of project finance loans has increased dynamically during the last two decades and takes up 5-10\% of the global corporate syndication loan portfolio.

Though importance is growing, problems and questions concerning the appropriate pricing of project loans are not discussed in the literature. Basel regulation inspired commercial banks to apply riskadjusted price calculations for their corporate loan exposures to create value for shareholders. Models and applications of banks were developed to calculate an art of "risk-adjusted rate on capital" of corporate loans compared to the expected "return on equity". However, risk and default parameters of project loans - as a key driver of pricing - are hard to measure, estimations of default probabilities rely on complex and individual cash-flow simulations. In our study, we set the research questions on whether project finance loans were properly priced based on their risk before and after the financial crises. We present the relevant characteristics of project finance and highlight its importance in current financial markets. We briefly present the framework of risk analysis in the case of projects, then, we take a model for appropriate risk-adjusted pricing used for standard corporate loans. We adapt the model to project loans and based on the model we focus on two results. First, we define the minimum required margins under which a project loan has surely no value added. Then we obtain a formula to estimate the "implied maximum probability of default" of projects, which serves as a risk-threshold, above that a project loan could not produce a value added to lenders.

Though the model is general, we have to choose a specific market and time for the analysis. We run our simulation based on the parameters of the European banking market environment of two periods (20062007 and 2016-2017). We take the necessary external input parameters from that market research, and - assuming different project loan margins and leverages - we estimate the implied maximum probabilities of defaults. We compare these maximum probabilities of default with reference points available from other empirical studies. In our calculations, we distinguish the construction and operation phases and also separate the simulation based on the changing financial market conditions before and after the financial crises. We summarise the main findings and conclusions of the simulation at the end and also refer to new market tendencies of 2018 and to their possible consequences.

\section{Project finance - structure and the market}

There is a wide variety of literature (textbooks, articles, research papers) describing the definition, structure, motives, advantages, and disadvantages of project finance (Nevitt-Fabozzi 2000, Gatti 2012, Yescombe 2013, Moody's 2013). Definitions are discussed in regulatory papers (CRR 2013) as well. Based on these definitions project finance can be described as the financing of a specific investment with a usually definite lifetime on a non-recourse or limited-recourse basis. The borrower is a legally independent SPV (special purpose vehicle), i.e. a project company, which is an important organizational feature of project finance. This is a form of "off-balance-sheet" financing, as assets and liabilities get 
Walter György: Risk-adjusted pricing of project loans

STUDIES IN ECONOMICS AND FINANCE 2019 p. 1 Paper: 10.1108/SEF-05-2018-0149 (2019)

https://www.emeraldinsight.com/doi/abs/10.1108/SEF-05-2018-0149

out of the sponsor company's balance sheet. (Esty et al. 2014) A structural feature of project financing is that financing relies mostly on a complex contractual structure and on the cash-flow provided by the project. Contract- and cash-flow based financing is different from the standard corporate lending, which is - besides cash flow availability - mainly based on the analysis of balance sheets, the historic operation, and performance of an operating company. Long maturities and high leverages are also typical attributes of project financing products. (Gatti et al. 2007, Gardner-Wright)

Standard project structures, participants and their roles, the contractual framework and the grouping of risk exposures are also presented in most of the project finance literature. (e.g. Esty 2014, GardnerWright, Moody's 2014) Besides the standard participants of a project structure (offtaker, suppliers, constructor etc.), there are some special stakeholders who could potentially step in and influence the overall risk of the financing. Especially in the case of investments in developing countries, Multinational Development Banks (MDBs) could appear as a key participant of the syndication to assist private investors to launch projects. Furthermore, due to the higher political and regulatory risk, the debt could be (partly) guaranteed by Export Credit Agencies (ECA) who often work together with MDBs. Some project loans are even guaranteed by the hosting government. Government support can be materialized in different forms from direct funding through contingent participation (like guarantees), or via financial intermediaries. (Worldbank 2016) That could materially affect the project risk level and even shift it to the sovereign level if the rating of the guarantor is better than the estimated risk level of the project. Based on empirical studies, one-third of the projects held some guarantees at the turn of 2000. (GriffithJones-Fuzzo de Lima 2004, Kleimeier-Megginson 2005)

Important risk characteristics of projects and project financing are the distinction between the construction phase and operation phase. Risk factors during the construction phase are usually referred to as completion risk. These focus on events that might occur before completion and basically before the start of cash flow production: delays, improper completion, cost overrun, force majeure, etc. After completion, the risks of the operation phase are due to the overall business, strategic, and market risk factors such as feedstock supply, sales, political, regulatory, operation and maintenances, currency, interest rate risk of the running project. (Gardner-Wright) The various risk profiles of the construction phase and operation phase of project finance appear clearly in the difference in default probabilities and recovery statistics, and therefore these affect loan pricing as well. (Moody's, 2013)

Project finance is a part of corporate loan portfolios and a sub-segment of the syndicated loan market. Due to the usually high financing volumes, projects are typically financed in syndications or in banking clubs. Kleimeier-Megginson (2005) compare the standard syndicated loan credits and project loans, and their study presents a full-scale empirical study of syndicated loans and project loans of that time. They find that project finance loans are more likely to be provided to riskier, developing countries, more likely to have a third-party guarantee, to involve more banks in the syndication, and have less covenant relative to average syndicated loans. However, besides syndicated project finance, we must be aware of the importance of smaller projects booked in banking portfolios, where volumes do not require syndicated financing. While we have a detailed database and several empirical studies concerning the syndicated loan market and big projects, the aggregated volume and characteristics of smaller project loans are much less transparent and not included in the studies, and this fact sets clear limitations for any overall analysis. 
Walter György: Risk-adjusted pricing of project loans

STUDIES IN ECONOMICS AND FINANCE 2019 p. 1 Paper: 10.1108/SEF-05-2018-0149 (2019)

https://www.emeraldinsight.com/doi/abs/10.1108/SEF-05-2018-0149

Most of the general project financing articles, research papers, and textbooks present the history, the development of the modern form of project loans. Empirical studies (Kleimeier-Megginson 2005, Moody's 2013, Winning 2013, DellaCroce-Gatti 2014) show that the dynamism of the last 15-20 years has become significant. The volume of project loans has been increasing rapidly, in recent years annual issues (around USD 200 billion) were four times bigger than the issues of the late 1990s, and 20 times bigger than that of the early 1990s. By 2013 the total cumulative exposure of the more than 7,600 reported projects reached a volume of USD 2,600 billion with an average size of approximately USD 350 million. Half of the projects are linked to North America and to Western Europe, to the two regions which were also highly dominant in 2000. Since then South East Asia has become the next dominant market with a growing proportion and currently representing $20 \%$ of total projects. More than half of the projects are related to infrastructure and the energy sector. Though global syndicated loan volumes are also steadily growing, the ratio of project loans is not decreasing. On the contrary, as project finance loans took up less than $5 \%$ of total syndicated loans in 2000, the annual project finance issues went up to $5-10 \%$ of total syndicated loan-issues by 2013 (Winning 2013). It is important to note again, that these statistics do not include smaller club-deal project loans or projects financed by project bonds. Yescombe (2013) estimates the total volume of new issues reached USD 300 billion in 2012, which is more than the published volume of the new syndicated project loan issues by $150 \%$.

It appears that the high demand for project finance as a product will continue the future. Even during the financial crises (except for 2009) the annual new loan provision did not decrease significantly. Based on different forecasts, needs for infrastructural investment and appropriate funding are enormous in the world, the demand for infrastructural investments are expected to reach USD 60-70 trillion through 2030. (Esty et al 2014)

We have a detailed database on the regional origin of projects and project loans. However, it is difficult to estimate how banks and, banking markets are exposed to project finance risk in different countries and regions. Banks do not publish their project finance loan portfolio and national banks have dispersed information bases and reporting standards relating to project portfolios in their domestic banking market. Nevertheless, we can gain some statistics from the ECB Database that could highlight the importance of these special financing vehicles in the balance sheets of European based commercial banks. One loan category that is reported to ECB is the "total exposures collateralized by immovable commercial property", which is assumedly dominated by project loans. Comparing these loan volumes to total corporate loan volumes we see that in some benchmark Western European countries (Austria, France, Belgium, Italy) the ratios of these loans reach 15-20\% while in Central Eastern Europe (Poland, Czech Republic) it is around $10 \%$. We have a detailed banking database available in Hungary including all project loans booked during the last five years. It shows that project loans took up $35-25 \%$ of all corporate loan exposures in Hungary in 2013-2017. (Walter 2017)

In the next chapters, we will discuss the basic terminology of project risk valuation and focus on the relevance of the construction phase and operation phase risk while presenting the basic literature of riskadjusted pricing. 
Walter György: Risk-adjusted pricing of project loans

STUDIES IN ECONOMICS AND FINANCE 2019 p. 1 Paper: 10.1108/SEF-05-2018-0149 (2019)

https://www.emeraldinsight.com/doi/abs/10.1108/SEF-05-2018-0149

\section{Project risk and risk-adjusted pricing methodology}

In respect to risk-adjusted prices, the key parameters most difficult to estimate and check are default risk and default probability. This is even more challenging for projects with a long maturity with specific conditions, where almost every loan is structured uniquely. Projects are more difficult to compare to past performances, it is hard to standardize them and the usual rating-based systems cannot be applied to measure credit risk. (Gatti et al 2007). The literature handling and measuring project finance risk is broad. Standard and Poor's (2001) evaluates project risk in six steps through operational, legal, strategic, business, regulatory risk analysis. Ravis (2013) distinguishes three general steps to analyse project risk: relevant project risk factors must be defined, relevant risks must be allocated to other stakeholders (via contractual structure), and finally, non-allocated risks must be handled. This logic explains the usual high leverage of project loans, the complex contract-based structure, and the necessity of modelling business plan cash-flows.

Due to increased volumes and regulatory requirements, the quantitative calculations of project risk and default probabilities have also become important. According to EBA (2016) technical standards, socalled "specialised lending exposure" must be measured in line with different criteria detailed in their proposal. On the other hand, Basel regulation also allows the introduction of an internal rating based approach where "probability of default" (PD), "loss given default" (LGD) "exposure at default" (EAD) values must be properly estimated. However, the methodology - due to lack of standardization, statistics, start-up project companies - differs from corporate models, which are based on annual statements and historical corporate statistics. Models for estimating default probabilities of projects usually adapt Monte Carlo-cash flow simulations and typical key questions relate to identifying relevant driving parameters, their probability distribution, and cross-correlations.

Important risk characteristics of projects and project financing are the distinction between the construction and operation phase. Parts of construction phase risk (completion risk) focus on events that might occur before completion and basically before the start of cash flow production (delays, improper completion, cost overrun, force majeure, etc.). After completion, the risks of operation are due to the overall business, strategic, market risk factors (supply, sales, political, regulatory, operation and maintenances, etc.) of the running project. (Gardner-Wright) The different risk profiles of construction and operation phases in project finance appear clearly in the difference in default probabilities, and recovery statistics, and therefore these affect loan pricing as well.

Basel Capital Accord has contributed to focusing on the risk awareness of lenders; commercial banks intended to measure risk and price loans correctly to create value for their shareholders. The regulatory and well-known theoretical framework of internal ratings-based valuation, the basic theory of credit portfolio management (Kealhofer 1997) also established the methodology for appropriate risk-adjusted price calculations. Several models and research works were published, and applications were introduced into everyday banking practices. The main questions in this research are as follows: How should final pricing of a specific corporate loan include different capital adequacy requirements, risk parameters, and other related cost elements to produce a value added to shareholders? How does the power of risk assessment models affect efficiency in pricing? How sensitive are risk-adjusted pricing to different parameter changes? 
Walter György: Risk-adjusted pricing of project loans

STUDIES IN ECONOMICS AND FINANCE 2019 p. 1 Paper: 10.1108/SEF-05-2018-0149 (2019)

https://www.emeraldinsight.com/doi/abs/10.1108/SEF-05-2018-0149

Dietsch-Petey (2002) assume a portfolio allocation process with several simplifying assumptions (oneyear maturity, a fixed recovery rate, no taxes, and operating costs). The lender maximizes the expected return under the exogenously given economic capital constraint. Assuming a given return on equity (ROE) level expected by the shareholder the minimal (risk-adjusted) loan price can be determined to reach this target on average. Repullo-Suarez (2004) also focus on the pricing implications of capital requirements. They analyse the transition effect from the standard approach to an internal ratings-based (IRB) approach in a strict theoretical framework under perfectly competitive market conditions, where loan default rates are driven by a single systematic risk factor. Beside other implications, they analyse the equilibrium loan rates of low and high-risk loans under the two risk measurement approaches. Stein (2005) examines how the power of risk models used by banks affects the profitability of credit portfolio management. He presents how returns on total portfolio exposure increase by having a more powerful model with a better (rating) cut off. If simple cut off is extended, and instead of an exact cut-off a flexible risk-adjusted pricing is used, then portfolio net present value (NPV) increases further. That leads to important pricing implications as it shows that a pricing model (and lending policy that allows lending to anybody, but only with appropriate expected revenue) that reflects the overall market price of risk leads to more profitable performance. He also shows that these economic benefits improve in a competitive landscape, where there are other banks with risk measurement models with different efficiency and level of explanatory power. Cases and results were illustrated with simulations backed by different credit parameters.

Hasan-Zazzara (2006) propose a methodology to calculate a risk-adjusted credit margin for corporate loans based on the main risk parameters of Basel II capital requirements. Their presented methodology is very close to current banking practices. They divided the pricing into two components. One covers the technical pricing relying on the internal based model parameters. This includes the risk-free rate, the regulatory capital requirement (ratio), the probability of default (PD) and the recovery rate of the loan in the event of default and the liquidity cost, which is the opportunity cost on the undrawn part of the loan. The second component is called the commercial part; this includes the cost of fund, fees and commission incomes, operational costs, and strategic considerations. The model concentrates on the technical part of pricing and derives the risk-adjusted rate (spread) of a loan. The risk-adjusted rate must cover both the expected loss and the unexpected loss. In the case of expected loss alone, the risk-adjusted rate must ensure that with the probability weight of the outcomes (non-default or default) the loan provides a risk-free rate. In the case of non-default, the outcome is the future value of the loan with the risk-adjusted rate; in the case of default is it the recovered (based on recovery rate) part of the loan. The unexpected loss is covered by the regulatory capital, therefore the remuneration for the unexpected loss is the cost of the regulatory (economic) capital times the amount of necessary capital. Based on the regulation regulatory capital is a portfolio of equity and subordinated loan, thus the cost of it is also a portfolio return of its elements. The risk-adjusted rate (or spread, i.e. the premium above the risk-free rate) must cover both expected loss and unexpected losses. Unlike practical models, the model does not consider the cost of fund or cross-selling incomes related to the loan. Finally, from the shareholder point of view, the RAROC (Risk-adjusted return on capital) is expressed, as the ratio of net income on the loan (the spread, margin of the loan plus commissions net operating, liquidity and expected risk costs) over the regulatory economic capital of the exposure. From RAROC the economic value added (EVA) can also be achieved by comparing RAROC with the market expected/required ROE, whether EVA is created for shareholders. 
Walter György: Risk-adjusted pricing of project loans

STUDIES IN ECONOMICS AND FINANCE 2019 p. 1 Paper: 10.1108/SEF-05-2018-0149 (2019)

https://www.emeraldinsight.com/doi/abs/10.1108/SEF-05-2018-0149

Curcio-Gianfrancesco (2011) developed a multi-period risk-adjusted pricing model using the framework of Hasan-Zazzara. They achieve an appropriate risk-adjusted price for a zero-coupon loan, then they model risk-adjusted spread in the case of various repayments (bullet, constant capital repayment, straight line amortization) loan structures. They analyse the contribution of the expected loss (EL) and unexpected loss (UL) of credit losses and also calculate the impact of maturity and loss given default (LGD) on risk-adjusted spreads in different risk classes and repayment structures.

In respect to the risk awareness and pricing of structured finance loans like project financing, it is common talk that commercial banks were not risk-averse enough before the financial crisis; terms and conditions of project loans were not set properly. Based on risk-adjusted pricing methodology we set the following research questions:

1. Did commercial banks in the European market measure and price the risk of project financing exposures properly in pre-crisis years of 2005-2007?

2. How do answers differ if we make a distinction between the construction and operation phase?

3. What is the parameter range where current project loans are adequately priced based on empirics available?

To analyse and answer these research questions we present the risk-adjusted pricing model, adapted it to project loans, and present the basis of our parameter setting, and finally, we run our simulation.

\section{Risk-adjusted pricing - the model applied}

Since 2006-2007 banks have also started to apply cash-flow simulation models to estimate project finance risk. No information is available on their accuracy. Some empirical, historical, global PD statistics were published (see later), but these data are applicable for practical credit management and for our analysis only with caution. These average figures and results can serve only as boundaries and reference points. As default probability is the most fragile parameter for answering our research questions and the usual logic is now reversed. If we know the methodology of acceptable risk-adjusted pricing models for corporate loans and other necessary input market parameters (like market pricing, leverage, funding costs, collateral valuation rules, etc.) are accessible, we can calculate the maximum implied PD of project loans that participating banks implicitly anticipated by the pricing and by the approval. Banks did not necessarily make price-risk adequacy calculations for each project before 2007 to get a proper risk-adjusted pricing. Models were likely to be available for standard corporate loans but unlikely for project loans. But every approval based on given terms and market conditions automatically results in a maximum implied PD as a boundary, under that the project loan provides a value added to shareholders. By comparing theses maximum implied PD with some reference points available we can make valuable conclusions concerning practices before 2008, and for the practices of today.

Basically, the simplest practical models used by commercial banks have the same approach and parameters as that of Hasan-Zazzara (2006). In these models there are some simplifications, nevertheless, they include general (technical) and some bank-specific (commercial) parameters, and indicate an expected ROE of the loan. Models were mainly used to measure the profitability and appropriate pricing of each new loan. Although it was applied mainly for standard corporate loans it is 
Walter György: Risk-adjusted pricing of project loans

STUDIES IN ECONOMICS AND FINANCE 2019 p. 1 Paper: 10.1108/SEF-05-2018-0149 (2019)

https://www.emeraldinsight.com/doi/abs/10.1108/SEF-05-2018-0149

also applicable to structured finance and project loans. The basic idea is that every new exposure must produce enough (expected) revenue, relative to its risk, and take all other costs into consideration (funding, administrative). Enough expected revenue means that final RAROC calculated on the economic capital must exceed the required ROE that the bank sets as a target. There are models, which go even further and calculate EVA (Economic Value Added), present values of all revenues and costs in a multi-period model. These models serve as a supporting tool that defines whether bank managers have priced the given loan properly. It offers an opportunity for risk management or senior management to intervene and modify price or cancel the transaction. Banks have also built up a pricing competence hierarchy similar to credit decisions if RAROC requirements are not met. Based on these models we can suppose, that before transactions commercial banks made some RAROC calculations and if they approved the project these results met these minimum return expectations.

In our model, following the basic RAROC structure of Hasan-Zazzara (2006), we take the simple oneperiod model, assuming a diversified portfolio of assets, where RAROC is calculated and compared to the required ROE of the commercial bank. The project asset value $(A)$ is assumed to be 100 and is financed from equity sponsorship $(E)$ and from a loan $\left(D_{0}\right)$, where $D_{0}$ also represents the leverage ratio. The loan requires the bank to allocate a given amount of economic capital, which is a percentage $(c)$ of the exposure based on the regulatory capital adequacy requirements.

A loan produces the following expected incomes and has expected costs.

The expected incomes on the loan are as follows:

- probability weighted (1-PD) interest margin $(M)$ income above the base rate $\left(R_{f}\right)$,

- up-front fees and commission incomes.

Expected costs of the loan are as follows:

- the funding cost of the loan (dependant on the base rate $\left(R_{f}\right)$ and the loan's funding cost spread above the base rate $(L)$ ),

- risk cost of the loan as a function of the PD and the $L G D$. $L G D$ is the risk-free future value of the loan $\left(D_{l}\right)$ less the liquidation value of the assets, where $C V$ is the collateral value of the Asset $\left(L G D=D_{1}-A \cdot C V\right)$,

- administrative/operational costs of the approval process.

In our model, we assume that all up-front fees and commission incomes cover exactly the total operational costs of the project loan. Furthermore, no-cross selling or future strategic revenue expectation is included in the calculation. As project loans are usually drawn down fully (at least by the end of the construction period), exposure at default $(E A D)$ is equal to the total loan $\left(D_{I}\right)$, and no liquidity cost (on undrawn part) is calculated.

Based on the following parameters we can define the expected RAROC of the project loan.

A Asset value of 100

$D_{0}: \quad$ leverage ratio (loan value to total asset value $(A)$ at the start of the project)

$D_{l} \quad$ loan value at the end of the period

$R_{f}: \quad$ base rate

$M$ : $\quad$ interest margin above the base rate 


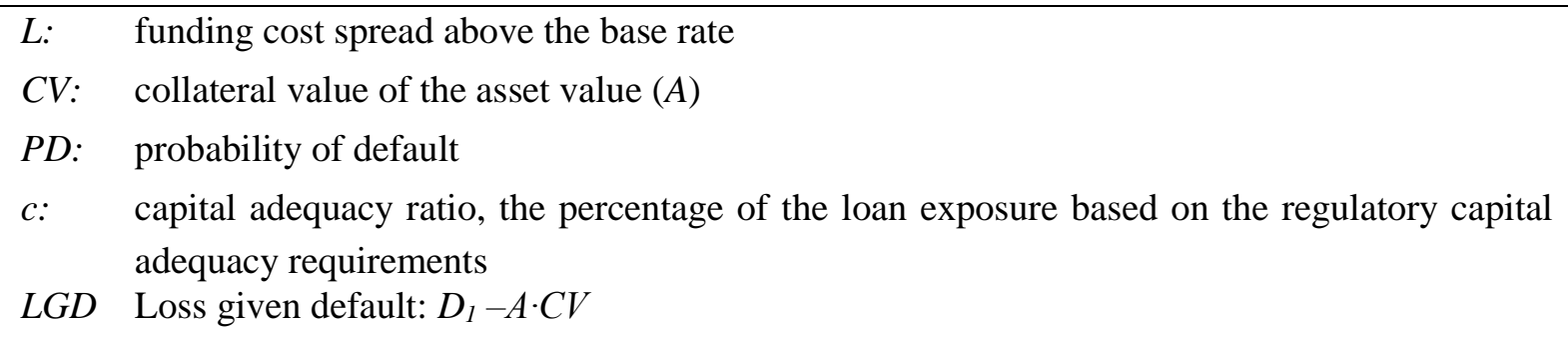

$$
R A R O C=\frac{(1-P D) \cdot D_{0} \cdot M-P D \cdot L G D-\left(D_{0} \cdot L-D_{0} \cdot c \cdot\left(R_{f}+L\right)\right)}{D_{0} \cdot c}
$$

In the numerator, we can find the net of the expected revenues, the risk cost, and the funding cost of the loan, in the denominator the economic capital used for the project loan.

To create value, RAROC must exceed the required ROE:

$$
R A R O C \geq R O E
$$

From (1) and (2) we express PD, and this gives us the formula for the maximum PD, the threshold in default probability, where the loan still produces the required ROE:

$$
P D_{\max }=\frac{D_{0} \cdot\left(M-L+c \cdot\left(R_{f}+L-R O E\right)\right)}{L G D+D_{0} \cdot M}
$$

where per definition

$$
\begin{gathered}
100 \% \geq P D \geq 0 \% \\
L G D \geq 0 .
\end{gathered}
$$

From formula (3) PD is non-negative if

$$
M \geq L-c \cdot\left(R_{f}+L-R O E\right) .
$$

This means that we could also calculate the minimum margin required to reach the expected ROE even with zero expected loss, that is, without risk:

$$
M_{\text {min }}=L-c \cdot\left(R_{f}+L-R O E\right)
$$

If we do not consider the competitive pressure from other banks, the key parameters where a bank has full decision autonomy: the leverage $\left(D_{0}\right)$ and the margin $(M)$. Therefore, in our simulation, we calculate the maximum PDs at a different leverage $\left(D_{0}\right)$ and the margin rates $(M)$ at a given ROE level based on formula (3). We compare these PDs-margin-leverage combinations with possible empirical PDs and reference points available from other research. For the calculations, we take the external parameters for the period before the crises first, i.e., for the years 2006-2007. Then we repeat our calculation with the parameters of after-crisis conditions. We will also distinguish the construction and operating phases of the projects in our simulation. 
Walter György: Risk-adjusted pricing of project loans

STUDIES IN ECONOMICS AND FINANCE 2019 p. 1 Paper: 10.1108/SEF-05-2018-0149 (2019)

https://www.emeraldinsight.com/doi/abs/10.1108/SEF-05-2018-0149

$\overline{\text { Except for leverage and the margin, we assume all other parameters as externally given. There are }}$ external market or project specific parameters like the regulatory capital adequacy ratio on total loan $(c)$, the risk-free market base rate of return $\left(R_{f}\right)$, the expected loss given default $(L G D)$ which relies on the market price of the asset $(A)$, and its collateral value $(C V)$ backed by recovery market and collateral valuation statistics. Bank specific external market parameters are the funding cost spread $(L)$ and the required minimum return on equity (ROE) of the bank. We gain indicative values for external parameters from the market, from empirical studies, and from the general collateral policies of banks.

The methodology is general and can provide an insight into project finance assumed default probabilities, minimum margins in the case of different lender groups, product groups or for different regional financial markets. We know that most of the external parameters differ in regional markets: funding costs can differ according to the size, and to the rating of banks, and also based on the regional financial markets. Capital adequacy requirement, minimum required ROE, or even collateral values and recovery statistics can differ from one region and country to another. In the next chapters and in our simulations, we chose to focus on the European market and to analyse the case of mid-sized European private banks with an investment grade around "A". We do not regard projects of Multination Development Banks as part of our analysis, as their pricing methodology does not necessarily consider profitability objectives and are largely influenced by political, regional development factors as well. We do not distinguish government or ECA guaranteed loans from other loans in our analysis, as all empirical statistics by parameter settings used in our simulation are based on overall empirical studies, where projects with guarantees are also included in the studies and results. On one hand, we believe that guarantees are less relevant in European project financing. On the other hand, we must note that this is a sub-segment of the project loan market with assumedly different average recoveries, benchmark PDs and leverages. For the time being no empirical study has focused exclusively on the unique empirical features of this segment. Once empirical details are available, it creates an opportunity for an eventual new simulation in respect to guaranteed projects in developing countries. Finally, in the case of a direct government-funded or fully guaranteed project where the guarantor has a better rating than the project risk, then project risk is defined by sovereign risk and risk-adjusted pricing becomes less complex or not even relevant, and no simulation is needed.

In the following chapters we will first estimate bank-specific parameters of a mid-sized European bank with a medium-strong investment grade based on empirical studies available. Then we will run our calculations for finding the implied maximum PDs for different margin-leverage scenarios both in the construction and operation phase.

\section{Parameter setting - empirics, reference points}

In order to run our simulation of the assumed maximum PDs - based on empirical research and other pieces of available market information - we have to gain and examine the following parameters of the model: recovery rates (i.e. collateral values, $C V$ ), base rate $\left(R_{f}\right)$, funding cost spread $(L)$, capital adequacy ratio $(c)$, required $R O E$. To facilitate a clear understanding of the results and to draw conclusions default statistics (PD) and leverage ratios $\left(D_{0}\right)$ statistics are also needed. Maximum PD results of the simulation then must be compared to the reference points of defaults statistics. 
Walter György: Risk-adjusted pricing of project loans

STUDIES IN ECONOMICS AND FINANCE 2019 p. 1 Paper: 10.1108/SEF-05-2018-0149 (2019)

https://www.emeraldinsight.com/doi/abs/10.1108/SEF-05-2018-0149

There are only a few empirical studies in the literature publishing project financing risk statistics of defaults and recoveries.

Beale et al (2003) published a result of an early study made by a pool of banks reacting to the strict Basel regulatory proposal. They examined a portfolio for the time horizon of 1999-2002, representing $24 \%$ of the global project finance market. They concluded that project finance has PD characteristics between a "BBB+"-rated corporate unsecured loans (long-term) and BB+-rated loans (short term). The 10 -year cumulative default rate is $7.5 \%$, and they set the average annual PD to $1.5 \%$ similar to a BB+ corporate loan. They also concluded, that project finance loans become less risky as they mature which corresponds to the major project finance risk nature, that construction and operating phase differs significantly. They found that the LGD of combined project finance portfolios of all banks was approximately $25 \%$ (recovery rate $75 \%$ ), and the individual average recovery rates of all participating banks were significantly above $50 \%$.

There is a very deep and broad analysis of the project finance market by Moody's (2013). They examined 4,067 projects from 1983-2011 and analysed regional and geographical PD and recovery statistics. Their findings are more sophisticated and, however, correspond to initial analyses made 10 years ago, while results show riskier project profiles. They also conclude that project finance is generally between the investment and speculative grade category. In European banks' internal rating tables, these risk categories mean an annual PD around $1 \%$. The very general simple average default rate for the whole population is $7.5 \%$, but as a very general number, this should be interpreted with caution. The 10 -year cumulative default rate is higher (from 7\% to 9-10\%). Marginal annual default rates during an initial three-year-long period following financial close are between 1.6-1.9\%. These correspond to the high speculative grade credit but fall significantly after the third year and dip below $1 \%$ after the fifth year. Infrastructure and power industries represent two thirds of total projects. Marginal default rates for infrastructural projects are better than the average, at about $1 \%$ in their first 1-4 years, however, in the case of the power industry it is slightly higher than $1.5 \%$. Default statistics of PPP projects are better than average projects, while average annual PDs are about two thirds of the average. Recovery statistics are also published in this analysis. Projects from restructuring reach an average RR of $80 \%$, however, in the case of distressed sales (which represent about a quarter of all defaults) this is much lower, at only $45-50 \%$. Restructured recovery statistics of projects defaulted during construction is much worse (60$65 \%$ ) than that during operation (above $80 \%$ ). It also proves that the risk profile of the project loan is different to standard corporate loans, and that the construction phase is largely different from the operating phase. This distinction and the use of different recovery rates as a crucial point of our model is dealt with in the next chapter. The surprisingly low average time to default (less than 3.5 years), the considerably higher initial marginal PD, and the substantially worse construction-phase recoveries also show that the two project phases must be handled differently.

As loan prices, margins and fund costs were usually linked to market rates such as LIBOR, EURIBOR, we therefore set the base rate $\left(R_{f}\right)$ to the average level of this time horizon at $3.5 \%$ p.a. Based on information from treasury experts and unpublished banking database we set funding cost spread $(L)$ above $R_{f}$ for long exposures at $30 \mathrm{bps}$ for 2006-2007. This corresponds to a fund cost of mid-sized European banks with a medium-strong investment grade around "A"-. This estimation is also supported by ECB (2009) and ACG (2014) reports. 
Walter György: Risk-adjusted pricing of project loans

STUDIES IN ECONOMICS AND FINANCE 2019 p. 1 Paper: 10.1108/SEF-05-2018-0149 (2019)

https://www.emeraldinsight.com/doi/abs/10.1108/SEF-05-2018-0149

$\overline{\text { In our model, we assumed a 100\% risk weight for project loans and first we assume } 6 \% \text { capital adequacy }}$ ratio $(c)$. That is higher than the Tier I level of Basel II (4\%) but less than the total capital requirements of $8 \%$. Based on experience the used equity requirement ratio for corporate loan risk-adjusted pricing applications in practice was around 6-7\%.

Average ROE in commercial banks was between 12-15\% in 2004-2007 (Damodaran 2017). Crucio (2011) suggests 800 bps risk premium for expected ROE in risk-adjusted pricing studies. We assume an expected minimum ROE of $12 \%$, which corresponds to all these studies and market figures.

Finally, however, we regard leverage ratios as a non-external parameter, there are studies calculating typical, average leverage ratios $\left(D_{0}\right)$ for project finance. Esty-Megginson (2003) - using a sample of about 500 project loans - analyse the distribution of syndicated tranches of project finance before 2000 . They report an average leverage of these projects of about 70\%. Esty et al (2014) update their earlier research and analyse leverage characteristics of project loans of 2009-2013. They find that $70 \%$ of all projects have a leverage rate higher than $70 \%$, and $13 \%$ of the total have higher than $90 \%$. Relative to their earlier studies the average leverage went up to $75 \%$. It is important to mention that in the segment of "property" $60 \%$ of project loans have a leverage rate higher than $80 \%$, with a mean of $80 \%$. Byoun et al (2013) report even much higher leverage ratios for the period of 1997-2006 examining more than 2,500 projects. In their project characteristic statistics, broken down by industries, they report an average leverage of $89 \%$, and on more than $90 \%$ by the two dominant sectors of utilities and constructions.

\section{Results of simulations}

In our analyses, we differentiate the construction case from operation phase as risk parameters differ significantly. In both cases, we set market parameters based on the empirics and regulation as follows. We take $30 \mathrm{bps}$ for long-term funding spread $(L)$. Basis rate 3M EURIBOR is set to a level of $3.5 \%$. We set the target ROE at 12\%, which corresponds to the practice of European banks in 2003-2008. Capital adequacy ratio $(c)$ is assumed to be $6 \%$. A key parameter is $L G D$, which is different in the construction phase and operation phase. We adjusted $L G D$ to harmonize with recovery statistics of Moody's (2013). Therefore, the collateral value of the asset $(C V)$ is $55 \%$ by the construction phase. By an $80-90 \%$ leverage ratio it corresponds to a recovery rate $(R R)$ on loans of $60-65 \%$ (that is the average $R R$ at the construction phase). This assumption is also supported by the fact, that the collateral value (final liquidation value) of real estates at commercial banks is usually between $50-70 \%$ of the market value regulated by their internal collateral policies. We do not consider any front-end fee, commission opportunities, strategic and customer relationship motivations to be related to pricing.

Based on risk-adjusted pricing, we first look at the one-year implied maximum PD of a project at the beginning of the construction phase. As empirics showed most project loans have a leverage above $70 \%$, we therefore focus our simulation on the 70-90\% leverage range. Table 1 shows the required minimum margin, and the maximum PDs in the construction phase according to different loan margins $(M)$ and leverages $\left(D_{0}\right)$ for years 2006-2007. 


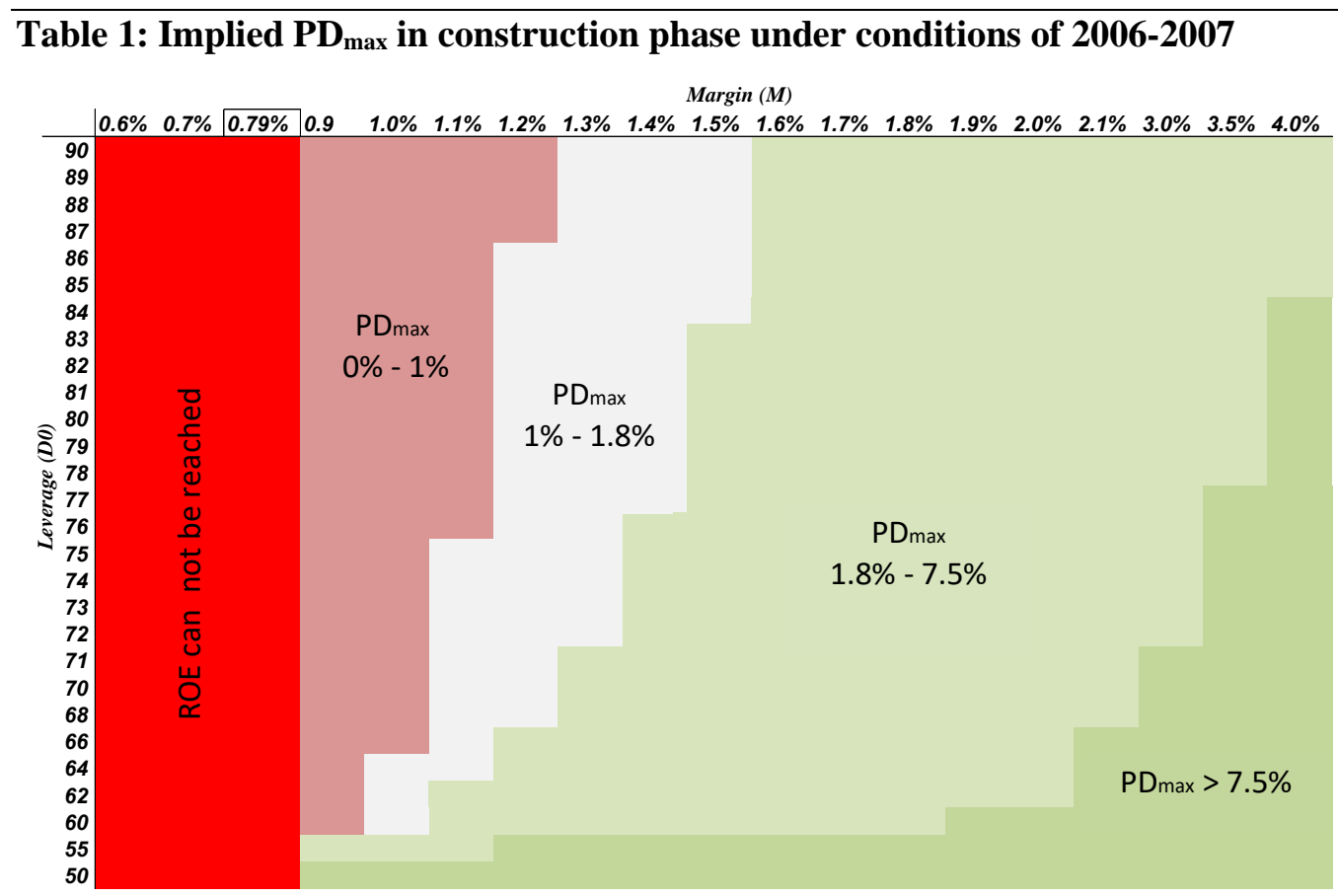

$$
\begin{aligned}
R f & =3,5 \% \\
C V & =55 \% \\
C & =6 \% \\
L & =0,3 \% \\
R O E & =12 \%
\end{aligned}
$$

The minimum margin that a loan - under the given parameters - must reach is $0.79 \%$, i.e. about $0.8 \%$. This is independent of leverage; and driven by the expected ROE, the general interest rate level, funding cost, and the capital adequacy ratio (see formula 4). It means, that even if the loan is expected to be riskfree ( $L G D$ is 0 and/or PD is 0 ), a long-term loan with a margin below $80 \mathrm{bps}$ is unable to produce value to the shareholder. These cases are highlighted in red in Table 1.

Based on empirics we do not find any project types where we could assume that annual PD is greater than $1.0 \%$ (see construction projects, PPP, similar corporate ratings). Therefore, we set the next reference point at $1 \%$. The leverage-margin pairs below the $1 \%$ implied maximum PD are presented in light red. Table 1 shows that margins less than $1.2 \%$ with a leverage higher than $75 \%$ will not produce enough expected ROE.

The next reference point can be the marginal PD of construction years of a general project. This is between $1.7 \%-1.9 \%$. The less risky project of a PD between 1.0\%-1.8\% (highlighted in white) must have an all-in margin of $1.3-1.5 \%$ if leverage is above $75 \%$. If we take the general average annual default rate of $7.4 \%$ of Moody's (2013) even high leverage transactions produce enough expected ROE if the margin is above $1.5 \%$. (Table 1 shows PDs of $1.8 \%-7.4 \%$ in light green, above $7.4 \%$ in dark green.) With a margin of 3\% implied PD almost reaches $5 \%$ even with $90 \%$ leverage.

Kleimeier-Magginson (2005) reports project margins of the largest project launched between 1980 and 2000. Margins are spread between 56-200 bps, many of them are below 100 bps. We know from the market, business reports, interviews (Schlor 2006) that motorway PPPs in CEE launched in 2006 had 
Walter György: Risk-adjusted pricing of project loans

STUDIES IN ECONOMICS AND FINANCE 2019 p. 1 Paper: 10.1108/SEF-05-2018-0149 (2019)

https://www.emeraldinsight.com/doi/abs/10.1108/SEF-05-2018-0149

(have) a margin of about 1.2\% with a leverage of close to 90\%. By 2007-2008 these margins - when banking consortiums were formed at the start of the project - went down further to $1 \%$ and leverages went up to $90 \%$. There are market comments stating that margins went down even to 0.6-0.7\% (Bain 2009, pp 29). We can conclude that even with an average recovery outlook projects under $1.2 \%$ all-in margins were very unlikely to be priced properly. Moreover, those loans where pricing fell below $1 \%$ (as in PPPs of 2007-2008) certainly did not produce a value added to shareholders. Easing the leverage to $65-75 \%$ - which often happened in the period of crisis - could largely improve the opportunity to produce the required ROE even with smaller margins.

We repeat our simulation in the case of the operation phase. In this case recovery, default statistics, and all reference points improve. Average recoveries are about $80 \%$, so we set collateral value $(\mathrm{CV})$ at $75 \%$, which harmonizes with these empirics. This means that with a leverage of equal or better than $75 \%$ the expected LGD and therefore EL is 0.

Table 2: Implied PD $_{\max }$ in operation phase under conditions of 2006-2007

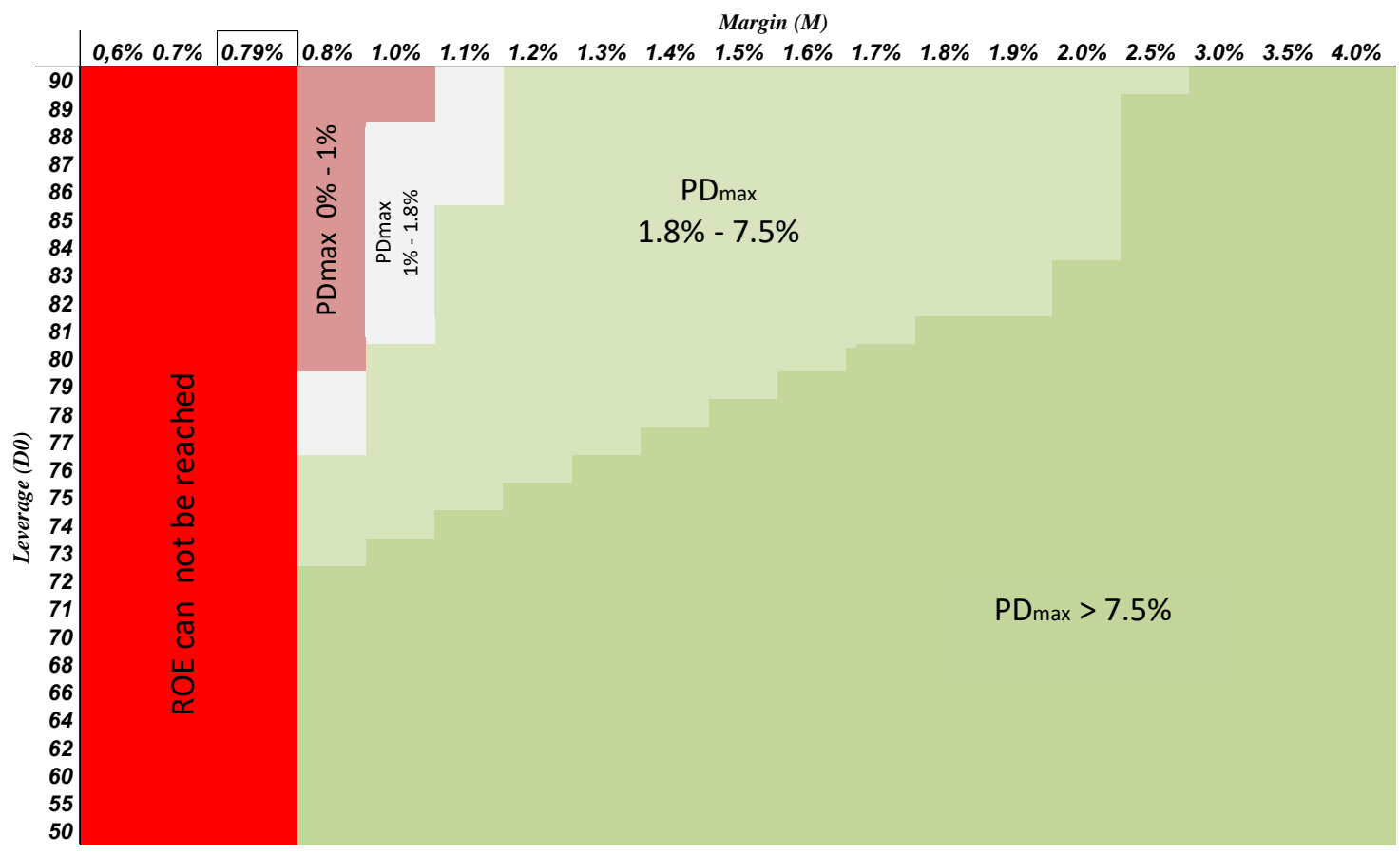

$$
\begin{aligned}
R f & =3,5 \% \\
\underline{C V} & =\frac{75 \%}{6 \%} \\
C & =6 \% \\
L & =0,3 \% \\
R O E & =12 \%
\end{aligned}
$$

We know that marginal PDs of an average project fall after three years and go below $1 \%$ after the fifth year. However, the minimum margin is independent of risk and recovery. Below a margin of $0.79 \%$, there is no value added loan under these parameters. But in the operation phase, a loan at high leverage (85-90\%), with a margin of 1.0\%-1.1\% could produce enough expected ROE. With these recoveries, a relatively low leverage of $70 \%$ and a margin of $1 \%-1.1 \%$ is surely enough for creating value for shareholders. Equity sponsors and banks were aware of the decrease in risk level after the construction 
Walter György: Risk-adjusted pricing of project loans

STUDIES IN ECONOMICS AND FINANCE 2019 p. 1 Paper: 10.1108/SEF-05-2018-0149 (2019)

https://www.emeraldinsight.com/doi/abs/10.1108/SEF-05-2018-0149

period. It is a well-known phenomenon in project financing that it is fully refinanced right after the construction. Leverage did not change; however, by revaluating, upgrading the assets, debt even increased reaching the same leverage at the end. Finally, as an answer to our second research question, our analysis shows that a decrease of about 20 bps in margins relative to construction financing can be justified; however, margins less than $1 \%$ (this happened in many projects in 2007-2008) still cannot be explained.

To answer our third question, the construction phase and the operation phase calculations can be repeated under market conditions of 2016-2017. During the last 10 years, funding cost has shown high volatility. Liquidity and country cost went up dramatically in 2009-2011 then decreased again. Funding cost $(L)$ of this era (of a similar bank as in our former case) was around $100 \mathrm{bps}$. On the other hand, basis rates went down; therefore, we set the base rate $\left(R_{f}\right)$ to $0 \%$. Capital requirements became stricter, Tier I capital ratio was increased from $4 \%$ to $6 \%$, therefore we reset $c$ to $8 \%$. The ROE of last few years was below the ROE figures of 2005-2007. European banks had an average ROE of 7.5\%, banks had an ROE of 9-10\% in 2016 globally (Damodaran 2017). Considering these facts and the fall of the base rate, we decrease the required $R O E$ to $9 \%$. In the construction phase, the collateral value remains $55 \%$, in the operation phase we set it to $75 \%$ again.

Table 3: Implied $P D_{\max }$ in construction phase under conditions of 2016-2017

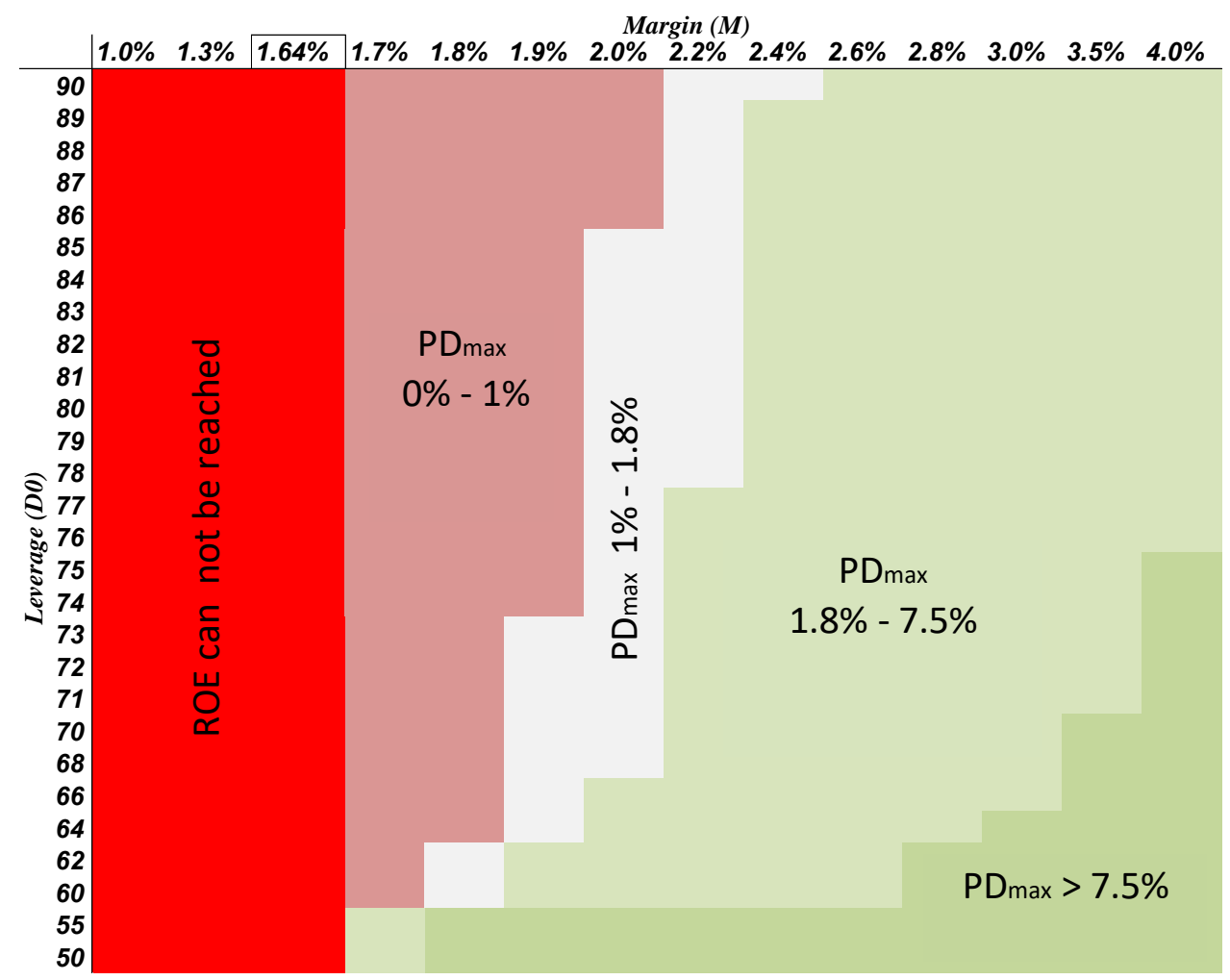

$$
\begin{aligned}
& \underline{R f}=\underline{\mathbf{0}, 0 \%} \\
& C V=55 \% \\
& \underline{c}=8 \% \\
& L=1,0 \% \\
& \underline{R O E}=\underline{\mathbf{9 \%}}
\end{aligned}
$$


Table 4: Implied $\mathrm{PD}_{\max }$ in operation phase under conditions of 2016-2017

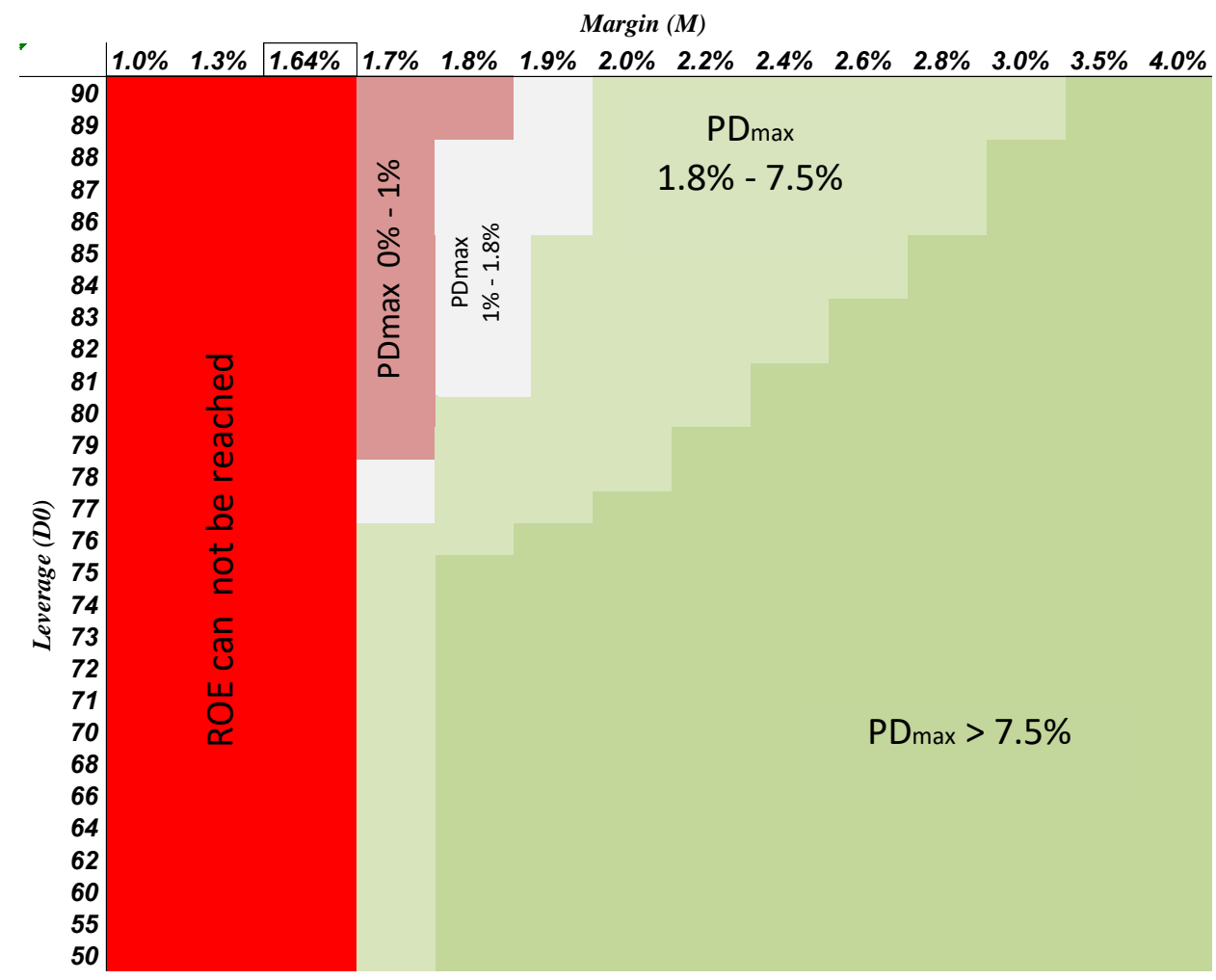

$\underline{R f}=\underline{0,0 \%}$

$\underline{C V}=\underline{75 \%}$

$\underline{c}=\underline{8 \%}$

$\underline{L=1,0 \%}$

$\underline{R O E}=\underline{9 \%}$

Results in Table 3 and in Table 4 differ significantly from previous calculations. Minimum (all-in) margin increased considerably to $1.64 \%$. In the construction phase high leverage (75-90\%) projects with a margin of less than $2 \%$ are hard to justify, either leverage must be eased, or the margin should be increased above $2 \%$ to be on the safe side. It can also be seen, that riskier projects (with a PD of around $5 \%$ ) with high leverage (85-90\%) must be priced with a minimum margin of $4 \%$ to reach the expected ROE.

Comparing the results of the four tables it can be stated, that the operation phase eases the risk level of construction in a way that the project completion allows a margin decrease of about 20-30 bps. This is also true under after-crisis conditions. Comparing the results of simulations of before- and after-crises conditions it can also be read that changes in conditions have influenced the acceptable margins by the projects in construction and in the operation phase in the same way. Comparing operation phase projects of 2006 to 2016 and construction phase projects of 2006 to 2016 we can state that margins must be up by about 80 bps to reach the same implied PDs (by the same leverages) in both cases.

If we included cross-selling, relationship-strategic considerations, and fees into our simulation then results and conclusions could change. However, banking sales experience shows that cross-selling 
Walter György: Risk-adjusted pricing of project loans

STUDIES IN ECONOMICS AND FINANCE 2019 p. 1 Paper: 10.1108/SEF-05-2018-0149 (2019)

https://www.emeraldinsight.com/doi/abs/10.1108/SEF-05-2018-0149

$\overline{\text { revenues by projects are much less than by standard corporate loans of the same size. Account turnover, }}$ fees are smaller; they use fewer products of commercial banks then normal companies. Strategicrelationship considerations are also weaker than in the case of corporate exposures, sponsors intentionally want to separate financing from their core businesses. Moreover, depressing the price is crucial due to tight cash flows, relatively high leverages, and financing costs. Finally, fees and commission by project loans can be significant at the start that could increase banking income. These must cover higher transaction costs and also serve as a part of margin compensation. Therefore, an allin margin is commonly calculated. However, fees are usually paid once, front-end, and should be evenly divided throughout the whole maturity, which significantly reduces the all-in margin increase effect. Assuming a certain refinancing in advance and dividing fees only among years of construction is not correct, though commonly used.

\section{Conclusions}

The risk-adjusted pricing toolset of corporate loans can be adapted to project finance loans. Though modelling of default probabilities of project loans, as a key driver of such models, is critical, the methodology can be still used to draw several valuable conclusions concerning adequate risk-adjusted pricing. Using different leverages and margins, thresholds of default probabilities can be calculated under different market conditions. Based on our model we simulated the maximum implied probabilities of default under the European banking market conditions before the crisis (2006-2007) and after the crisis (2016-2017). We also distinguished construction and operation phases, which is decisive by project loans' risk profiles. Though in our simulation we assumed external market parameters of a midsized European bank, the model is general. The framework of the simulation allows the modification and resetting of external market and regulatory parameters (like the base rate, fund cost, capital adequacy) if available. This makes it possible to adapt it to non-European banking markets, and to other lender groups of project finance or to current or future market parameters as well.

First, we analysed project financing in its construction phase before the outbreak of the financial crisis. Based on our calculation the minimum margin that a loan must reach is about $0.8 \%$. Results show that margins below $0.8 \%$ were unable to produce value for the shareholder. Knowing historical PD statistics of project loans, we believe that project loans with a margin less than $1.2 \%$ and with a leverage higher than $75 \%$ did not produce enough expected ROE even with the most optimistic risk assumptions. As we definitely know such specific project cases (like PPPs of 2007-2008), we can conclude and answer our first research question, that these pricing practices - depressing the margins under $1.2 \%$, later even under $1 \%$ with a leverage of $90 \%$ - had produced negative value added for lenders. Even less risky projects should have had an all-in margin of 1.3-1.5\% if leverage is above 75\%. On the other hand, implied PDs show that project loans with a margin of $3 \%$ are very likely to have value added even with an extreme leverage. We also concluded that getting back to a more conservative leverage of $65-75 \%$ (like in the financial crisis-era) could largely improve the opportunity to produce the required ROE even with smaller margins.

If a project loan enters the operation phase, recovery, default statistics and thus reference points improve. This creates room for more aggressive pricing and leverages. However, below a margin of $0.8 \%$, there was still no value-added loan in 2006-2007 even in a risk-free operation phase. On the other hand, a 
Walter György: Risk-adjusted pricing of project loans

STUDIES IN ECONOMICS AND FINANCE 2019 p. 1 Paper: 10.1108/SEF-05-2018-0149 (2019)

https://www.emeraldinsight.com/doi/abs/10.1108/SEF-05-2018-0149

margin of 1.0\%-1.1\% at high leverage (85-90\%) could produce enough expected ROE. The project loan with an average leverage of $75 \%$ at a margin more than $1.0 \%$ was surely on the profitable side. This explains the usual refinancing transactions (at 20-30 bps lower margins and with increased leverage) after closing up constructions, however, this still does not justify margins below $1 \%$ at an extreme leverage of $90 \%$. The potential decrease of $20-30$ bps also appears in the simulation based on after-crises conditions, and this result justifies potential future refinancing transactions after 2016-2017.

Market and regulatory conditions had significantly changed by 2016-2017, which also implied a more conservative risk-adjusted pricing in the construction as well as in the operation phase. The minimum (all-in) margin doubled to $1.64 \%$. Based on our results credit approvals of construction-phase projects at high leverages (75-90\%) with margins below $2 \%$ are hard to justify. The required margins to a given level of leverage (of construction phase project loans) went up by 90-100 bps in comparison with the market of 2006-2007 to 2016-2017.

Decreasing funding costs can create new room for less conservative risk-adjusted pricing practices, while competition in the lending sector becomes more and more intense again. Based on ECB surveys and reports (ECB 2018a, 2018b, 2018c, p8-9) the credit standards (banks' internal guidelines or loan approval criteria) for loans to enterprises eased considerably throughout 2018. The decreasing margins on riskier loans, less conservative credit terms (collateral requirements, covenants, maturity and loan size) contributed to the overall easing of terms and conditions to corporate loans. This raises a further question whether the banking sector is driving itself into the same aggressive pricing practices of 20062007 , i.e. into the red zone of our simulation, again. 
Walter György: Risk-adjusted pricing of project loans

STUDIES IN ECONOMICS AND FINANCE 2019 p. 1 Paper: 10.1108/SEF-05-2018-0149 (2019)

https://www.emeraldinsight.com/doi/abs/10.1108/SEF-05-2018-0149

\section{References}

ACG Analytics (2014) Cost of funds on European Banks. ACG Analytics, Washington DC, October

Bain R (2009) Review of Lessons from Completed PPP Projects Financed by the EIB. EIB, June

Beale C, Chatain M, Fox N, Bell S, Berner J, Preminger R; Prins (2002) Credit Attributes of Project Finance. Journal of Structured \& Project Finance. Fall, Vol. 8 Issue 3, pp 5

Byoun S, Kim J, Yoo S (2013) Risk Management with Leverage: Evidence from Project Finance. Journal of Financial and Quantitative Analysis, Vol. 48, No. 2, Apr., pp 549-577

Chiara N, Garvin M J (2008) Variance models for project financial risk analysis with applications to greenfield BOT highway projects. Construction Management and Economics, September, 26, pp. 925939

Capinski M (2007) A model of credit risk based on cash flow. Computers \& Mathematics with Applications 54, pp 499-506

CRR - Capital Requirement Regulation - REGULATION (EU) No 575/2013 OF THE EUROPEAN PARLIAMENT AND OF THE COUNCIL https://eur-lex.europa.eu/legalcontent/en/TXT/?uri=celex\%3A32013R0575

Curcio D, Gianfrancesco I (2011) A risk-adjusted pricing model for bank loans: Challenging issues from Basel II. Journal of Risk Management in Financial Institutions Vol. 4, 2, pp 117-145

Damodaran online (2007) http://pages.stern.nyu.edu/ adamodar/ (downloaded on 29th of August, 2017)

Della Croce R, Gatti S. (2014) Financing infrastructure - International trends. OECD Journal: Financial Market Trends Volume 1

Dietsch M, Petey J (2002) The credit risk in SME loans portfolios: Modelling issues, pricing, and capital requirements. Journal of Banking and Finance, Vol. 26, Nos. 2-3, pp. 303-322.

Dong F, Chiara N, Kokkaew N, Xu A (2012) Copula-Based Portfolio Credit Risk Assessment in Infrastructure Project Financing. The Journal of Private Equity, Spring

EBA (2016) EBA/RTS/2016/02, 13 June 2016 FINAL draft Regulatory Technical Standards on Assigning Risk Weights to Specialised Lending Exposures under Article 153(9) of Regulation (EU) No 575/2013 (Capital Requirements Regulation - CRR)

ECB (2009) EU Banks’ Funding Structures and Policies - May 2009. Frankfurt, ECB

ECB (2018a): The euro area bank lending survey - First quarter of 2018, April; https://www.ecb.europa.eu/stats/ecb_surveys/bank_lending_survey/html/index.en.html

ECB (2018b): The euro area bank lending survey - Second quarter of 2018, July https://www.ecb.europa.eu/stats/ecb surveys/bank lending survey/html/index.en.html

ECB (2018c): The euro area bank lending survey - Third quarter of 2018, October; https://www.ecb.europa.eu/stats/ecb_surveys/bank_lending_survey/html/index.en.html

ECB Database - Statistical Data Warehouse https://sdw.ecb.europa.eu/ 
Walter György: Risk-adjusted pricing of project loans

STUDIES IN ECONOMICS AND FINANCE 2019 p. 1 Paper: 10.1108/SEF-05-2018-0149 (2019)

https://www.emeraldinsight.com/doi/abs/10.1108/SEF-05-2018-0149

Esty B C, Megginson W L (2003) Creditor Rights, Enforcement, and Debt Ownership Structure: Evidence from the Global Syndicated Loan Market. Journal of Financial and Quantitative Analysis, Vol. 38, No 1, March

Esty B C, Chavich C, Sesia A (2014) An Overview of Project Finance and Infrastructure Finance2014 Update BACKGROUND NOTE | HBS CASE COLLECTION | JUNE 2014 (REVISED JULY 2014) https://www.hbs.edu/faculty/Pages/item.aspx?num=47358

Gardner D, Wright, J: Project Finance Chapter 12 HSBC

https://www.hsbcnet.com/gbm/attachments/products-services/financing/project-finance.pdf

Gatti S, Rigamonti A, Senati F S M (2007) Measuring Value-at-Risk in Project: Finance Transactions. European Financial Management, Vol. 13, No. 1, pp 135-158

Gatti S (2012) Project Finance in Theory and Practice, II Edition, Academic Press, San Diego.

Griffith-Jones S, Fuzzo de Lima A T (2004) Alternative Loan Guarantee Mechanisms and Project Finance for Infrastructure in Developing Countries Institute of Development Studies, University of Sussex, http://www.ids.ac.uk/ids

Hasan I, Zazzara C (2006) Pricing risky bank loans in the new Basel II environment, Journal of Banking Regulation 7(3-4) · May

Kealhofer S (1997): Portfolio Management of Default Risk. KMV Corporation

Kleimeier S, Megginson W L (2005) Are project loans different from other syndicated credits? Journal of Applied Corporate Finance 13 (1)

Kwak H K, Ingall L (2007) Exploring Monte Carlo simulation applications for project management. Risk Manag. 9, pp 44-57

Moody's (2013) Default and Recovery Rates for Project. Finance Bank Loans, 1983-2011. Moody's Investors Service. Feb. 4

Nevitt P K, Fabozzi F J (2000) Project Financing, 7th Edition, Euromoney Books

Repullo R, Suarez J (2004) Loan pricing under Basel capital requirements. Journal of Financial Intermediation, Vol. 13, No. 4, pp. 496-521.

Ravis J G (2013) Risk Analysis Paramount in Project Financing Decisions. Natural Gas \& Electricity. Nov, Vol. 30 Issue 4, p1-7.

Riemer S, Wagner C (2015) An efficient approach for calculating default probabilities for cash-flow based project finance with reserve account. Computing and Visualization in Science, Volume: 17 Issue 4

Schlor M (2006) M6 Motorway-Hungary. "Regional Workshop on PPP in Highways“, Belgrade 6th 8th June, presentation

Standard and Poor's (2001): Project Finance Summary Debt Rating Criteria, Standard and Poor's

Stein R M (2005) The relationship between default prediction and lending profits: Integrating ROC analysis and loan pricing / Journal of Banking \& Finance 29, pp 1213-1236 
Walter György: Risk-adjusted pricing of project loans

STUDIES IN ECONOMICS AND FINANCE 2019 p. 1 Paper: 10.1108/SEF-05-2018-0149 (2019)

https://www.emeraldinsight.com/doi/abs/10.1108/SEF-05-2018-0149

Walter Gy (2017) The Risks of Project Finance - Based on International and Domestic Experiences. Public Finance Quarterly, 4

Winning A (2013) Thomson Reuters - GLOBAL SYNDICATED LOANS REVIEW MANAGING UNDERWRITERS 2013 Full Year 2013

World Bank (2016) Government Support in Financing PPPs, https://ppp.worldbank.org/public-privatepartnership/financing/government-support-subsidies

Yescombe E R (2013) Principles of Project Finance. Academic Press 